G

COUNTERFUTURES

Left thought \& practice Aotearoa 


\section{Editorial A resurgent left}

\section{Dylan Taylor}

SSUE TWO OF Counterfutures arrives in a time of great hope and momentum - coming, as it does, on the back of the Social Movements, Resistance and Social Change III conference (SMRSCIII), which this journal hosted. The organisers of this conference expected it to be a relatively low key affair. The first of these conferences attracted around 50 attendees and participants. ${ }^{1}$ The second conference, held at the Auckland University of Technology in 2015, had a little over 200 delegates attend. ${ }^{2}$

1 See Ozan Nadir Alakavuklar and Andrew Dickson, Social movements, resistance and social change in Aotearoa/New Zealand, Kotuitui: New Zealand Journal of Social Sciences Online 11/2 2016, for more on this conference and its context, and the rest of Kotuitui 11/2 for conference proceedings.

2 See Nathalie Jaques, Campbell Jones, Anna-Maria Murtola and Shannon Walsh, 
Given the smaller size of Wellington relative to Auckland, it was expected this year's iteration would have around 120-150 people in attendance. How wrong we were. Clearly there is something in the air - a strong desire from those interested in social justice and radical change to come together, to share ideas and stories, to develop relationships with one another, and to work towards a better future. Over the three days the conference ran at Victoria University of Wellington (1-3 September 2016), over 400 attended from around the country and further afield, with over 100 presenting papers, participating in panels or facilitating workshops.

Not that we should be carried away by numbers alone. As buoying as the wide support for the conference was, perhaps of more significance was the range of interests and groups that came together. It is this diversity, we contend, that makes it such a landmark event for the contemporary Left in Aotearoa.

The Left in this country, as elsewhere, underwent a historic period of fracturing, confusion and melancholy. By the late1960s/early-1970s the 'old gods' of socialism were seen to have failed. Those who kept the faith on the radical Left split into ever smaller sects - with more energy spent on denigrating one another than pursuing social and economic justice. In this period a family of social movements - loosely associated with the spirit of the 'new Left' - came to the fore: ongoing resistance to the war in Vietnam; a deepening opposition to the country's sporting ties with apartheid South Africa; a generation of young Māori revived the struggle for tino rangatiratanga; the Polynesian Panthers effective championing of the rights of Pacific migrants in Aotearoa; second wave feminists, responding in no small part to a frustration with existing Left practices, developed considerable momentum; LGBTQI+ activists came to the fore; and, to conclude this by 
no means exhaustive list, an emboldened environmental movement began to chalk up significant victories. ${ }^{3}$ Most of these movements were anti-capitalist, or at least capital-critical, but the outmoded structures of the 'organised' radical Left were unable to bring these diverse, yet interlinked, struggles together. While affinities between groups and movements existed, the overall arc of this period for the Left was one of divergence - of groups finding it more productive to work on their own issues than to collaborate with others. The fourth Labour government, when it came to power in 1984, was able to begin addressing some of the 'cultural' concerns raised by social movements. It also oversaw the rapid imposition of neoliberalism. The story from this point forward is one, largely, of scattered resistance and defeat - an already fractured Left was further undermined by the changing economic, political, cultural and social conditions of the country. ${ }^{4}$

It is with this history in mind that we underline just how important the recent conference was in terms of the diverse groups and voices that came together. Consider this list compiled from some of the conference stream titles:

- Tino Rangatiratanga \& Te Tiriti o Waitangi, Māori Activism

- Voices from Across Our History: A Discussion of LGBTQ Activism and Law Reform within Aotearoa New Zealand

- Indigenous Rights and Decolonisation in the Pacific

- Peace and Protest

- Work, Commodification, Reproduction and Resistance

3 I draw here upon my work in Dylan Taylor, What's Left? Unpublished Master's thesis, Victoria University of Wellington 2008.

4 Although it should be noted that considerable resistance did persist, see Toby Boraman, The Myth of Passivity, Red \& Green 5, 2005; and Maria Bargh, ed., Resistance, Wellington 2007. 
- Health, Disability, Activism

- Intergenerational Feminism

- Climate Action, Systemic Change, and the Significance of Hope

- Taking Back the Economy for People and the Planet

- Civil Disobedience: Climate Justice and Peace ${ }^{5}$

In addition, the conference hosted the launch of the No Pride in Prisons manifesto Abolitionist Demands ${ }^{6}$ - which highlights the intersections of ethnicity, gender, sexuality, class and capital in relation to incarceration - and of Economic and Social Justice Aotearoa (ESRA) - a think tank whose kaupapa includes 'Working to build a radical left hegemony in Aotearoa, based on ... social, economic and ecological justice, honouring tino rangatiratanga and grounded in Te Tiriti o Waitangi. ${ }^{7}$ The significant role that unions (the PSA and CTU to be precise) played in supporting the conference, along with the support of Victoria University of Wellington and Massey University, show there is a lot of cross-sectorial support in play. All in all, then, when considering the range of topics addressed, and of groups and organisations involved, there appears to be a widespread desire to see significant substantive change - and, when considering such events as the launch of ESRA, that an infrastructure is being developed to carry this forward.

It appears we are entering, then, a period in which the long-divergent strands of a fractured Left are beginning to once again be woven together. What might come of this possibility de-

5 The full conference programme and list of abstracts are currently hosted on the Counterfutures website: http://counterfutures.nz/smconference.html

6 Ti Lamusse, Sophie Morgan, and Emilie Rākete, eds., Abolitionist Demands, Auckland 2016.

7 Economic and Social Research Aotearoa, About, https://esra.nz/about/ 
pends on what we all, collectively, come to enact in our relations with one another in the years to come, and in the projects we initiate and work on. There are, of course, no end of tensions to still be addressed among us, and much learning to be done. ${ }^{8}$ Perhaps one of the most profound, challenging and potentially liberating sites of work in the years to come concerns the relation of the tauiwi and Pākehā Left to struggles around tino rangatiratanga and decolonisation - both Annette Sykes and Moana Jackson, in their talks at SMRSCIII, offered critical yet comradely challenges in this respect. It is hoped that the pages of this journal will be a site in which these discussions can be extended.

* $\quad * \quad *$

Through no design of our own - as this was a 'general issue' - the range of topics covered in this issue of Counterfutures speaks to the general dynamic outlined above: namely, that we are, loosely speaking, entering a period of possible convergence (of issues and organisations) following a long period of divergence.

Anna Fielder's article, which opens this issue, speaks to the historical tensions between Marxism and feminism, of the ways capital has been able to co-opt aspects of the feminist project, and argues that the Left must step into the thick of these tensions and contradictions. As argued by Fielder, a fundamental challenge for 'contemporary radicalism is the nurturing of political subjectivities that do not operate from the safety of fixed and incontestable identities or theories, but rather are capable of negotiating more tenuous spaces'. ${ }^{9}$ Or as stated by Tim Corballis in his 'intervention' in this issue, 'I think of the Left as a place where doubt, and self-doubt, are virtues'. ${ }^{10}$

8 See, for instance, Sue Bradford, Fractured Fightback, Counterfutures 12016.

9 Anna Fielder, this issue, p. 59

10 Tim Corballis, this issue, p. 194. 
Reflecting on the current conjuncture, it is possible that the tensions within the Left - historic tensions - can become productive sites when approached in an open manner. The search for fixity, for surety, the notion that a 'pure doctrine' to inform thought and practice can be developed, no longer appears necessary nor compelling. Rather, difference is accepted as simply that which is; how one works with this, and seeks to build commonalities across supposedly 'divergent' struggles, is what is important. This is not to abandon visions of social transformation, of building solidarity and political organisation. It is to begin such projects anew, informed by the struggles of the past, attentive to the tensions of the present, and attuned to future possibilities.

Brodie Fraser's article, Queerly Beloved, further extends our thinking of the tensions between past and present, and how these might be harnessed to drive us forward. In considering the passing of marriage equality for members of the LGBTQI+ community a range of issues are present: that this is not an end point for struggle, but rather one more step on the way towards equality; that the state, whose impact has been historically destructive for members of this community, is also a valid (though always problematic) avenue through which to extend the struggle; that generational rifts exist within the community that need to be overcome; and that the range of issues facing members of this community have significant overlaps with those of other groups. Consistent with the message coming from the work of No Pride in Prisons, there is a material dimension of inequality cutting through and intersecting with issues pertaining to gender, sexuality, ethnicity and class. The basis for solidarity is ever more clear, the need for fighting on multiple fronts as part of a shared struggle ever more apparent.

While the lines along which to extend political struggle are becoming clearer for those on the radical Left, those in power are seeking to depoliticise the practice of politics - aiming in- 
stead for the post-political space of friction-free consensus - a point that Keith Tudor's article on the flag debate (or lack thereof) highlights clearly. As he concludes:

If we can take anything from this expensive mistake, I would hope it would be that the next debate about the flag should be based on and in a political debate about the constitution of our country, based on relations between tangata whenua and non Māori (Pākehā and tauiwi), which a new flag would then represent. ${ }^{11}$

The Left needs to turn to the past as it moves to the future, to step onto a terrain of tension and potential conflict, rather than obscure the truly political behind the rhetoric of consensus.

In thinking through the place that conflict and tension can play for the Left - as productive spaces of becoming rather than traumatic sites to be disavowed - contemporary political theory offers plenty to chew on. In the long night of the Left there was a retreat, of sorts, into the academy by many on the 'intellectual Left'. ${ }^{12}$ Here, faced with the neoliberal revolution and narratives around the 'death of class', many of those grounded within Marxism extended the resources of this tradition with psychoa-

\footnotetext{
11 Keith Tudor, this issue, p. 112

12 The history of intellectuals on the Left being, of course, a fraught one, and the division between 'intellectuals' and 'rank and file' has been far from clear cut. Italian Marxist Antonio Gramsci carefully teased out some of the issues here with his distinction between 'traditional' intellectuals (the professionals) and 'organic' intellectuals (those who direct the interests and ideas of their class), see The Prison Notebooks, London 1971, pp. 3-23. In speaking here of an 'intellectual Left' I do not intend a distinction between 'thinkers' and 'doers'. Much important and sophisticated thought has stemmed from activists operating completely outside of the academy. In using the category here, however, I am indicating that there has been a tendency - in the period of the decline of the party, and the waning power of unions - for the site of Left critical thinking to have increasingly become that of the academy. Further, as more and more of the population has had access to university education (as problematic as this now is in the era of high student loans) the conditions for the emergence of 'organic intellectuals' who have not had some contact with the academy have diminished somewhat. None of this is to glorify the academy, a space in which serious discussions of the importance of class, capital and inequality have been largely been 'out of fashion'. For more on this later point see Dylan Taylor and Sandra Grey, From Class Struggle to Neoliberal Narratives, New Zealand Sociology, 29/3 2014.
} 
nalysis. ${ }^{13}$ In particular, the vexing question of the 'Subject' presented itself - along with its relation to ideology.

In the period of Left fracture discussed above, there was, then, a concomitant attempt by some within the academy to understand what it meant to be of the radical Left when class had lost its mobilising power, social movements had replaced the party, and society was increasingly individualised. In the sphere of electoral politics, why, critics asked, were so many willing to support politicians like Reagan and Thatcher or, today, figures like John Key, when doing so appeared to run counter to their material interests? Psychoanalysis offers the Left a means of supplementing and extending the materialist basis of its thought through considerations of the unsteady, conflictual and shifting terrain of the self.

Just as society is never a tightly bound, consistent wholebeing as it is a complex multiplicity, shot through with contradictions - so too is the individual non-whole, inconsistent and multiple. Self-knowledge is, subsequently, traumatic. Ideology - in promising wholeness, consistency, the fulfilment of our desires offers a means of obscuring trauma, hence its hold upon so many. From this perspective, radical politics begins with 'traversing the fantasy' of the full, consistent, society ${ }^{14}$ and recognises the contingent nature of our own sense of self and the way this sense of self reinforces dominant social structures. To return to the argument closing Fielder's article: there is a need for radical politics to step into sites of tension and conflict, rather than pass them over on the search for some imaginary wholeness and harmony.

13 This was already been an established line of research for Marxism, particularly for the Frankfurt School and their engagement with Freud. See for instance, Herbert Marcuse, Eros and Civilisation, London 1972.

14 Slavoj Žižek, The Sublime Object of Ideology, London and New York 2008, p. 141. 
Slavoj Žižek, perhaps more than any other contemporary theorist, has worked to extend the Left's critical engagement with psychoanalysis. ${ }^{15}$ This issue of Counterfutures includes two articles that fruitfully draw upon Žižek's work as a means of understanding contemporary political issues in Aotearoa.

Cindy Zeiher and Josiah Banbury engage with Žižek's work to consider the role ideology plays in this country's politics - especially with respect to the increasingly mediatised, spectacular form of electoral politics in play. The rise of the Mana Party promised a return to a more class-based form of politics, one able to critically challenge the dominant ideology. When Mana entered its coalition with the Internet Party, however, it became ever-more mired in the spectacular dimension of politics. The chance to build an alternative ideological platform (a counterhegemony), a more populist position, failed to bear fruit. There is a need for the Left in Aotearoa to constructively think through what happened with the Mana-Internet alliance - given that it was an attempt to harness the energy of social movements (the Mana movement) to a run at electoral politics.

Returning to the question posed earlier, as to why so many will support a figure like John Key when doing so appears to run contrary to their material interests, Warwick Tie's article draws upon Žižek, along with other contemporary theorists, to critically appraise what allows Key to hold such wide appeal. The problem of subjectivity under capital is, here, a principal concern. That we are compelled to be 'entrepreneurs of the self' under neoliberal capital, Tie argues, undermines attempts to develop a coherent sense of self. Given this, the figure of Key becomes an 'ideal' subjective type - someone who we may aspire to be,

15 Žižek, The Sublime Object of Ideology, is a seminal work here, although he is far from alone. See also: Alain Badiou, Being and Event, London 2005; Jodi Dean, Crowds and Party, London and New York 2016; Frederic Jameson, Valences of the Dialectic, London and New York 2009; and Ernesto Laclau, On Populist Reason, London and New York 2007. 
but more importantly (for those in power) someone who, through their public office, pragmatically displaces the insecurities and instabilities of capital. Key is an ideological figure. He tells us not to worry - he is 'comfortable' with what is happening, so we should be too. Tie explores the potential for a radical politics to emerge against such a figure. He writes: 'Against the individualistic contentedness projected by the figure of Key, a need arises to imagine how a collective, cooperative, subject might form anew ...., ${ }^{16}$ and consider the role the party (reconceived, recreated) might play, not just in a straightforward political sense, but also, importantly, on an affective level.

While seemingly abstract and at times difficult to grasp (although the effort is always rewarded), the insights to be gleaned from engaging with critical theory provide valuable conceptual tools for the Left in Aotearoa today. A long history of anti-intellectualism runs through this country, which has been particularly problematic for the Left. ${ }^{17}$ With this is in mind, it is exciting for this journal to be in a position of supporting authors who are not afraid of engaging in extended, difficult, theoretical appraisals of our political scene.

This is not a pastime reserved for the academy. As seen in the interview with Kassie Hartendorp in this issue, the importance of theory, of extended critical analysis, is prized by those working in a more explicitly activist space too, although Hartendorp also signals the need to engage seriously with Mātauranga Māori and Pacific knowledges. In her address at the ESRA launch she argued that there is a tendency in this country to prize European thought and thinkers over and above indigenous thinking. Another space of productive tensions opens. 'If indigenous people were given a space to be able to think about what system would

16 Warwick Tie, this issue, p. 144. Original emphasis.

17 See, on this issue, Bryce Edwards' discussion of Bruce Jesson and anti-intellectualism, http://liberation.typepad.com/liberation/2008/01/nz-intellectu-3.html 
work for them', she contends, 'I don't think that would look like capitalism'. ${ }^{18}$

Two 'interventions' from members of the Counterfutures editorial board also appear in this issue. Sean Phelan considers the implications of the possible media merger of the Australianowned companies APN and Fairfax in the Aotearoa market, a merger whose implications cannot, he shows, be separated from the logics of neoliberalism and the post-political turn. Tim Corballis offers a series of provocative reflections, prompted by the writing of Hungarian philosopher G. M. Tamás, as to what is at stake - subjectively, collectively - in seeking to think beyond capital. This topic receives further elaboration in David Parker's review of Paul Mason's Postcapitalism.

Dougal McNeill closes this issue of Counterfutures with a review of Jenny Lawn's Neoliberalism and Cultural Transition in New Zealand Literature, a work he considers to be 'a landmark in the history of materialist criticism in the New Zealand social formation ... ${ }^{19}$ In the context of our discussion here, Lawn's book appears as another instance of an emboldened critical voice in this country - another signal that we are waking from the long night of the Left.

* $\quad * \quad *$

A cautious optimism, we believe, is reasonable when considering recent developments from the Left in this country. Divergent strands are re-converging and transforming through our encounters with one another. There are more of us than we realised. A realistic appraisal of the need to productively engage with tensions - tensions with others, tensions within our very selves is apparent. Bold voices are speaking out. Rather than submit

18 Kassie Hartendorp, Neoliberalism as a colonizing project, 2016, https://esra.nz/ neoliberalism-as-a-colonising-project/

19 Dougal McNeill, this issue, p. 212 
to neoliberal orthodoxy - which holds politics is best left in the hands of professionals, and that there is no alternative to capitalism - a newly emboldened radical Left is emerging. What may yet come is unknown, but these are exciting times. 
If you like what you have read, please subscribe or donate.

\author{
G \\ COUNTERF UTURES \\ Left thought \& practice Aotearoa \\ (C) Copyright Counterfutures 2016
}

